Abdul Rozak \& Eva Fauziah: Implementasi Lesson Study

\title{
IMPLEMENTASI LESSON STUDY SEBAGAI UPAYA PENINGKATAN KOMPETENSI PEDAGOGIK GURU BAHASA INDONESIA DI SMP KABUPATEN CIREBON
}

\author{
Abdul Rozak \\ Eva Fauziah \\ FKIP, Unswagati Cirebon \\ Korespondensi: Jl. Pemuda No.32 Cirebon 45132 Telp. (0231) 236742 \\ Pos-el: rozak_euy@yahoo.com
}

\begin{abstract}
Abstrak
Lesson study merupakan alternatif yang dapat dilakukan oleh guru bersama teman sejawatnya dalam rangka membudayakan belajar sepanjang hayat untuk terus meningkatkan kompetensi pedagogiknya secara mandiri yang berdampak langsung bagi perbaikan dan peningkatan mutu pembelajaran di dalam kelas. Oleh karena itu, implementasi lesson study sebagai model pembinaan dan peningkatan kompetensi pedagogik guru bahasa Indonesia memerlukan dukungan dari pihak-pihak terkait terutama kepala sekolah dan dinas pendidikan. Tanpa dukungan itu, maka lesson study hanyalah "mimpi" bagi guru-guru yang memiliki motivasi untuk meningkatkan kemampuannya. Penelitian ini dilakukan untuk mengetahui pengaruh lesson study pada kompetensi pedagogik guru bahasa Indonesia SMP kabupaten Cirebon. Berdasarkan hasil penelitian ini lesson study berdampak positif terhadap kompetensi pedagogik guru.
\end{abstract}

Kata-kata kunci: lesson study, kompetensi pedagogik, peningkatan mutu pembelajaran

\begin{abstract}
Lesson Study is an alternative that teachers can take in implanting the culture of lifelong learning and improving their pedagogical competency independently. In addition, it has direct impact on the improvement and development of instructional quality in classrooms. Therefore, the implementation of Lesson Study as a model for improving the competency of Indonesian language teachers needs to gain support from all stakeholders, especially Principal and Office of Education in district level. Without the support, Lesson Study is just a "dream" for teachers who are highly motivated to improve their competencies. This research intended to find out the impact of Lesson Study on pedagogical competency of Indonesian language teachers in junior high schools in Cirebon Regency. This research found that Lesson Study gave positive impact on their pedagogical competencies
\end{abstract}

Keywords : lesson study, pedagogic competence, quality learning improvement 



\section{PENDAHULUAN}

Observasi Peneliti antara bulan April sampai dengan Desember 2011 di beberapa sekolah serta amatan di sekolah tempat mengajar sejak tahun 1989 sampai dengan sekarang menunjukkan bahwa masih ada guru-guru yang tidak mempunyai motivasi berubah atau tidak mampu berubah setelah mengantongi sertifikat pendidik. Guru-guru tersebut tidak menunjukkan peningkatan mutu kinerja sebagai guru profesional. Tunjangan profesi yang diterimanya bukan untuk meningkatkan kualitasnya sebagai tenaga profesional, tetapi untuk keperluan lain yang bersifat konsumtif. Pembelajaran di kelas masih tetap bersifat transfer ilmu dengan iklim yang tetap "konvensional" (JICA, 2009:1), yakni guru berdiri di depan para siswa berceramah kepada siswanya dengan suara yang tegas dan lantang dengan sesekali menulis di papan tulis. Fokus utama guru adalah bagaimana mentransfer berbagai macam informasi yang tercantum pada buku teks kepada siswa. Guru tidak pernah berpikir tentang minat dan perhatian siswa selama pembelajaran. Pada situasi lain ditemukan rencana pembelajaran (RPP) dibuat jika akan ada supervisi dari kepala sekolah dan dibuat sekadar memenuhi kewajiban administratif. Pembelajaran yang dilakukan di dalam kelas berbeda dengan RPP yang dipersiapkan. Sebagai contoh, dalam kegiatan inti pembelajaran dituliskan diskusi kelompok, tetapi kenyataan di kelas guru menggunakan metode ceramah dan siswa mendengarkan. Setelah itu, guru memberi soal, siswa mengerjakan secara individual. Penilaian kinerja guru oleh kepala sekolah dan dinas pendidikan melalui pengawas belum memperolah hasil yang memadai.

Keingintahuan yang sangat kuat mengenai implementasi lesson study membawa Peneliti mengikuti tahap do dan see pada putaran kedua program lesson study MGMP Matematika Kabupaten Cirebon di SMP Negeri 1 Karang Sembung pada 6 Oktober 2011. Dari amatan yang dilakukan di sekolah tersebut, Peneliti memperoleh gambaran bahwa lesson study mampu membangun suasana kekeluargaan dalam kolaborasi, baik pada saat pra open yakni briefing yang dipimpin oleh kepala sekolah dan penjelasan singkat dari guru model tentang pembelajaran yang akan dilaksanakan pada hari itu, maupun pada saat refleksi. Saling melihat pembelajaran yang dilakukan orang lain, saling membantu mencari pemecahan masalah dalam pembelajaran, tidak saling menyalahkan, dan suasana pembelajaran di dalam kelas berlangsung kondusif karena diperhatikan oleh banyak orang menjadikan siswa tidak main-main dalam belajar, seluruh aktivitas siswa pun dapat dipantau dengan baik. Selanjutnya, sekolah yang siap melaksanakan lesson study untuk mata pelajaran Bahasa Indonesia adalah SMP Negeri 2 Gunung Jati dan SMP Negeri 2 Plered. Lesson study yang dilakukan di kedua sekolah tersebut adalah lesson study berbasis sekolah.

Penelitian dilakukan pada empat SMP di Kabupaten Cirebon, dua sekolah yang belum melaksanakan lesson study dan dua sekolah yang sudah melaksanakannya, yakni SMP Negeri 2 Gunung Jati, SMP Negeri 3 Sumber, SMP Negeri 2 Plered, dan SMP Negeri 2 Greged, dengan menggunakan metode penelitian studi kasus. Penelitian ini bertujuan memperoleh gambaran secara utuh pelaksanaan lesson study dalam pembelajaran Bahasa Indonesia terkait pembinaan dan peningkatan kompetensi guru. Dari tujuan tersebut dapat dideskripsikan hal-hal berikut, yaitu (1) model lesson study sebagai upaya pembinaan kompetensi pedagogik guru bahasa Indonesia, (2) dampak implementasi lesson study terhadap profil kompetensi pedagogik, guru 
bahasa Indonesia, (3) dampak lesson study terhadap mutu pembelajaran di dalam kelas.

Penelitian ini dilandasi oleh pemikiran bahwa kompetensi guru mencakup kemampuan yang sangat beragam di antaranya kemampuan teknik, kemampuan pengambilan keputusan, kemampuan merefleksi secara kritis ("technical ability, decisionmaking capability, critical reflection capability"). Technical capabilities merupakan kemampuan teknik instruksional yang diperlukan untuk mengarahkan siswa pada kegiatan yang efektif. Kemampuan ini mencakup penggunaan dasar-dasar proses pengajaran, katerampilan, dan prosedur pengajaran untuk menciptakan pengalaman bermakna bagi siswa. Decision-making capability adalah kemampuan pengambilan keputusan yang melibatkan penentuan pilihan dan menghasilkan tindakan sebagai alternatif penafsiran pada saat pengajaran maupun dalam perencanaan, baik jangka pendek maupun jangka panjang. Kemampuan untuk menentukan pilihan memerlukan pengetahuan, pemahaman, dan penguasaan kompetensi dasar. Misalnya, kapan pendekatan induktif atau deduktif digunakan dalam pembelajaran. Kemampuan ini penting dalam penyusunan tujuan dan perencanaan pengajaran. Critical reflection capability adalah kemampuan merefleksikan pengajaran secara kritis, membutuhkan pengamatan dan analisis serta mempertimbangkan etika dan moral. Refleksi dapat meningkatkan pengembangan profesional karena didasari pengetahuan dan hubungan dialogis yang berkelanjutan. Agar efektif, refleksi harus didasarkan kondisi nyata di dalam kelas (Lang,dalam Mulyana:2007).

Suasana pembelajaran di dalam kelas bergantung kepiawaian guru mengelola kelas. Sebagai fasilitator, ia adalah faktor kunci yang memegang kendali pembelajaran. Oleh karenanya guru harus selalu siap ketika memasuki kelas. Kesiapan yang dimaksud menurut Lang dalam Mulyana (2007) adalah pembelajaran, strategi, dan bahan ajar ("A teacher is in her classroom. The lesson has been prepared, strategies thought out, and materials are ready"). Selanjutnya, tidak hanya kesiapan fisik dan materi, rasa nyaman antara guru dan siswa pun perlu dibangun. Hal itu dapat terjadi jika seorang guru menyukai dan menghormati murid-muridnya. Ketika seorang guru merencanakan pelajaran, maka kepentingan dan kemampuan siswa dipikiran dengan saksama ("She enjoys and respects her students, and when she is planning her lessons, keep their interest and abilities in mind"( Lang dalam Mulyana, 2007). Hal itu perlu dipahami oleh guru sebab ia dituntut untuk dapat mengupayakan "proses pembelajaran yang interaktif, inspiratif, menyenangkan, menantang, memotivasi untuk aktif, kreatif, mandiri sesuai bakat, minat, dan perkembangan fisik dan psikologis peserta didik." (pasal 19 PP 19, 2005). Untuk mencapai amanat pasal 19 tersebut, seorang guru tidak hanya mampu membelajarkan siswa tetapi juga "mampu selalu memantau setiap individu siswa dalam pembelajaran" (JICA, 2009:4). Dalam hal ini, guru bukanlah manusia super yang mampu mengembangkan kompetensinya secara "single fighter". Guru adalah manusia dengan segala "fitrah" keterbatasannya. Oleh karenanya, ia perlu berkolaborasi dengan mitra sejawat, di antaranya melalui lesson study.

Lesson study dilaksanakan dalam tiga tahap (Hendayana, 2006:10; Mulyana, 2007:5; Susilo, 2011:32) yaitu "tahap pertama adalah plan (merencanakan), tahap kedua adalah do (melaksanakan), dan tahap ketiga adalah see (merefleksi)". Tahap perencanaan 
(plan) menurut Hendayana (2006:11) dan Susilo (2011:35) bertujuan "menghasilkan rancangan pembelajaran yang dapat membelajarkan siswa secara efektif dan berpusat pada siswa, membangkitkan partisipasi siswa dalam pembelajaran. Perencanaan yang baik tidak dilakukan sendirian tetapi dilakukan bersama (kolaborasi)". Tahap pelaksanaan (do) pembelajaran untuk menerapkan rancangan pembelajaran yang telah dirumuskan dalam perencanaan. Seorang guru yang telah disepakati sebagai guru model mengimplementasikan rancangan pembelajaran. Guru-guru lain bertindak sebagai pengamat (observer) pembelajaran. Fokus pengamatan diarahkan pada kegiatan belajar siswa dengan berpedoman pada instrumen yang telah disepakati pada tahap perencanaan. Tahap do diawali dengan briefing yang dipimpin oleh kepala sekolah atau penanggung jawab lesson study. Briefing dimaksudkan untuk memberikan gambaran sekilas dari guru model mengenai pembelajaran yang akan dilaksanakan. Pada kesempatan ini diingatkan pula kepada para observer untuk tidak mengganggu jalannya pembelajaran. Tugasnya hanya melakukan amatan berdasarkan instrumen tanpa intervensi pada proses pembelajaran. Observer diperkenankan mendokumentasikan pelaksanaan pembelajaran dengan menggunakan kamera digital maupun kamera video.

$$
\text { Tahap refleksi (See) }
$$

dimaksudkan untuk menemukan kelebihan dan kekurangan pelaksanaan pembelajaran. Diskusi diawali dengan penyampaian kesan pemikiran guru model terhadap pembelajaran yang baru saja berlangsung. Selanjutnya, guru yang bertugas sebagai observer menyampaikan komentar dan pandangan terhadap pembelajaran. Pengamat dari luar sekolah, narasumber, menyampaikan apa lesson learned
(Susilo, 2011:36) yang dapat diperoleh dari pembelajaran yang baru berlangsung terutama yang berkenaan dengan aktivitas siswa dalam pembelajaran.

\section{METODE}

Penelitian ini menggunakan metode kualitatif yang berlangsung dalam latar yang wajar (natural) dengan berupaya memahami meaning of events dari apa yang diamati (Idrus, 2009; Santana, 2010). Metode ini disebut juga sebagai metode artistik (Sugiyono, 2011: 7) karena proses penelitian bersifat seni (kurang terpola) dan disebut sebagai metode interpretatif karena hasil penelitian berkenaan dengan interpretasi data yang ditemukan di lapangan.

Peneliti mengkaji profil kompetensi pedagogik guru sebelum dan sesudah melaksanakan lesson study. Sebagaimana penjelasan terdahulu bahwa penelitian yang dilakukan bersifat natural, Peneliti berkoordinasi dengan Dinas Pendidikan dan Kebudayaan Kabupaten Cirebon mengenai pelaksanaan program lesson study untuk mata pelajaran bahasa Indonesia tingkat SMP di Kabupaten Cirebon. Jawaban dari pihak Dinas mengenai waktu pelaksanaannya masih belum dapat dipastikan. Oleh karena itu, Peneliti memilih untuk menggunakan teknik simultaneous cross sectional (Muhadjir, 2002:55) yakni mempersingkat waktu observasi dengan cara pengambilan subjek yang berbeda. Dalam hal ini, penelitian dilakukan tidak pada satu subjek, tetapi multisubjek. Subjek penelitian diambil dari sekolah-sekolah yang telah melaksanakan lesson study yakni SMP Negeri 2 Gunung Jati dan SMP Negeri 2 Plered serta sekolahsekolah yang belum melaksanakan lesson study yakni SMP Negeri 3 Sumber dan SMP Negeri 2 Greged. Dengan demikian dapat diteliti profil guru yang belum melaksanakan lesson 
study dan profil guru yang sudah melaksanakan lesson study.

Penelitian dimulai dengan identifikasi masalah yakni masalah yang muncul setelah mengikuti open class di SMP Negeri 2 Gunung Jati. Untuk mempertajam masalah penelitian, maka refleksi dan penafsiran awal harus dilakukan (Raco, 2010:103). Untuk keperluan tersebut, Peneliti melakukan pengumpulan data awal pada 28 September 2011 di SMP Negeri 2 Plered dengan mewawancarai seorang fasilitator lesson study Kabupaten Cirebon. Dilanjutkan mengikuti proses do dan see di SMP Negeri 1 Karang Sembung pada 5 Oktober 2011.

Selanjutnya, dilakukan tahap literature review (Raco, 2010:104) yaitu tinjauan pustaka atas bahan tertulis berupa buku, jurnal, dan bahan secara online yang membahas masalah lesson study. Tahap ini membantu Peneliti melihat ide-ide, pendapat, dan kritik tentang masalah penelitian tersebut yang dibangun dan dianalisis oleh para peneliti sebelumnya. Tahap berikutnya adalah pengumpulan data. Setelah data diperoleh, kemudian dilakukan interpretasi dan analisis data. Tahap akhir dari penelitian adalah Penelitian hasil penelitian (laporan penelitian).

\section{HASIL DAN PEMBAHASAN}

\section{Persiapan Pembelajaran di SMP yang Tidak Melaksanakan Lesson Study}

Persiapan pembelajaran di SMP Negeri 3 Sumber dilakukan oleh guru untuk memenuhi kewajiban formal kelengkapan administrasi. Oleh karena itu, RPP yang dipersiapkan oleh guru untuk keperluan supervisi akademis adalah RPP "mentah" yang belum dikembangkan atau disesuaikan dengan kebutuhan siswa. Sebagai contoh, dalam kegiatan inti terdapat kalimat "dalam kegiatan eksplorasi guru татри bercerita dengan urutan yang baik, suara lafal, intonasi, gesture, dan mimik yang tepat". Kegiatan yang disebutkan itu belum merupakan kegiatan nyata guru di dalam kelas. Bandingkan, jika kalimatnya diubah menjadi "guru mencerikatan cuplikan novel Laskar Pelangi dengan ekspresi yang tepat dan siswa mendengarkannya dengan sungguh-sungguh". Dalam kalimat itu, kegiatan guru dan siswa tergambar dengan jelas. Contoh lain, "dalam kegiatan elaborasi guru memfasilitasi peserta didik melalui pemberian tugas, diskusi, dan lain-lain untuk memunculkan gagasan baru baik secara lisan maupun tulisan." Kegiatan yang dimaksud tersebut merupakan kegiatan yang abstrak dan membingungkan untuk dilakukan. Bandingkan jika kalimat diubah menjadi "siswa melaporkan hasil diskusi kelompoknya di depan kelas, kelompok yang lain menanggapinya."

LKS (lembar kerja siswa) yang dibuat oleh guru tidak sesuai dengan rancangan penilaian dalam RPP. Kompetensi yang akan dicapai siswa dalam RPP adalah mendengarkan, tetapi yang dikembangkan dalam LKS adalah kompetensi membaca. Soal-soal yang dikembangkan dalam LKS tidak sesuai dengan indikator pencapaian kompetenasi dalam rancangan penilaian.

Persiapan pembelajaran di SMP Negeri 2 Greged berlatar belakang sekadar ada RPP sebagai persyaratan administratif. Yang penting bagi guru, ia memiliki RPP sekalipun seragam dengan guru lain bahkan sekolah lain (dalam hal ini RPP di SMP Negeri 3 Sumber). Bagi guru, RPP bukan untuk mempersiapkan pembelajaran yang akan disampaikan di kelas melainkan sekadar "jaga-jaga" jika ada pengawas datang dan menanyakan RPP. Dengan bangga, guru menjelaskan bahwa RPP yang ia miliki hasil unduhan dari internet sebab ia tidak berkesempatan mengikuti MGMP (Musyawarah Guru Mata Pelajaran). 
RPP langsung dicetak melalui komputer kemudian dijilid rapi sehingga terlupakan untuk melengkapinya. Identitas RPP belum lengkap, tidak tercantum nama sekolah dan tidak mencantumkan titi mangsa, serta belum ditandatangani oleh kepala sekolah, kecuali tanda tangan guru yang bersangkutan. Dengan demikian, guru tidak membuat persiapan pembelajaran, ia masuk kelas dengan berbekal LKS cetakan sebuah penerbit.

\section{Persiapan Pembelajaran di SMP yang Telah Melaksanakan Lesson Study}

Persiapan pembelajaran

dilakukan oleh guru di SMP Negeri 2 Gunung Jati melalui koordinasi dengan tim lesson study di sekolah tersebut. Guru berupaya maksimal mempersiapkan pembelajaran yang akan disampaikan kepada siswa di kelas. Begitupun di SMP Negeri 2 Plered, guru berupaya maksimal dalam mempersiapkan pembelajaran. Bahkan sebelum dilaksanakan di dalam kelas, guru tersebut membahasnya secara kolaboratif dalam fase plan (perencanaan). Dengan demikian, guru dapat meminimalisasi kemungkinan kesulitan yang akan dihadapi di dalam kelas. Hasil penelitian di sekolah-sekolah itu diuraikan dalam paragraf berikut ini.

Persiapan pembelajaran di SMP Negeri 2 Gunung Jati dilakukan oleh guru melalui koordinasi dengan tim lesson study yang telah dibentuk dalam rapat terbatas antara kepala sekolah dengan para wakil kepala sekolah. Tim lesson study diketuai oleh wakil kepala sekolah bidang kurikulum. Ketika menyusun RPP, guru memikirkan kondisi dan kebutuhan siswa.

Tujuan pembelajaran dirumuskan berdasarkan standar kompetensi dan indikator. Materi pembelajaran diuraikan dan mengaikannya dengan konteks kehiduapan di sekitar siswa. Langkah- langkah kegiatan pembelajaran disusun secara sistematis. Sebagian menggambarkan secara jelas kegiatan guru dan siswa, sedangkan sebagian lagi kegiatan guru dan siswa tidak tergambar jelas. Sebagai contoh adalah kegiatan yang dirumuskan sebagai berikut. (1) Bersama kelompoknya siswa menulis petunjuk melakukan sesuatu dengan menggunakan bahasa yang efektif. (2) Setelah selesai menulis bahasa petunjuk, tiap-tiap kelompok mempresentasikannya dan memberikan tanggapan. (3) Guru bersama peserta didik menyimpulkan hasil pembelajaran. Kegiatan yang dirumuskan menggambarkan dengan jelas kegiatan yang dilakukan siswa dan kegiatan yang dilakukan oleh guru. Contoh kegiatan yang tidak tergambar jelas anatara lain (1) melibatkan peserta didik mencari informasi yang luas dan dalam tentang topik/tema materi yand dipelajari, bandingkan dengan rumusan sebagai berikut "seorang siswa maju ke depan kelas untuk membacakan petunjuk yang terdapat dalam kemasan, siswa yang lain mendengarkan. Setelah selesai, guru dan siswa bertanya jawab tentang petunjuk yang baru saja dibacakan. (2) Memfasilitasi peserta didik untuk memperoleh pangalaman bermakna dalam mencapai kompetensi dasar, bandingkan dengan rumusan berikut ini, "Guru menanyakan kepada siswa apakah akibatnya jika kita tidak membaca terlebih dahulu petunjuk yang ada pada kemasan obat?" pada bagian penilaian, instrumen penilaian disesuaikan dengan indikator pencapaian kompetensi.

Persiapan pembelajaran di SMP Negeri 2 Plered dilakukan secara kolaborasi dalam kegiatan plan. RPP yang sudah dibuat oleh guru model dibicarakan untuk mendapatkan masukan dari peserta lesson study. Sehingga guru berkesempatan merevisi RPP sebelum disampaikan kepada siswa dalam bentuk 
pembelajaran. Segabai contoh, sebelum pelaksanaan plan kelompok yang dibentuk oleh guru berjumlah lima sampai dengan enam orang untuk kegiatan menulis memo. Hal itu, menurut pendapat koleganya tidak tepat sebab jumlah lima atau enam terlalu banyak untuk mengerjakan Penelitian memo sehingga dikhawatirkan tugas kelompok tidak efektif. Untuk meminimalisasi kemungkinan ketidakefektifan kelompok, maka disarankan mengurangi jumlah kelompok hanya tiga atau empat orang saja.

Guru yang lain menyoroti kegiatan siswa, disarankan pada saat presentasi kelompok tidak perlu semua kelompok ditampilkan karena tugas yang dikerjakan oleh setiap kelompok tidak berbeda. Cukup dua kelompok saja yang ditampilkan masing-masing membahas memo yang berbed yaitu memo resmi atau memo tidak resmi. Sedangkan kelompok yaang tidak presentasi memberikan tanggapan atau sanggahan. Waktu yang tersisa digunakan untuk kegiatan menyunting hasil tulisan kelompok lain. Sehingga waktu dua jam pelajaran dapat dikelola seefektif mungkin. Dengan demikian, sebelum memasuki kelas, guru sudah mempersiapkan pembelajaran secara maksimal.

\section{Pelaksanaan Pembelajaran di SMP yang Tidak Melaksanakan Lesson Study}

Pembelajaran yang dilaksanakan di SMP Negeri 3 Sumber dan SMP Negeri 2 Greged tidak efektif. Hal itu terjadi karena pembelajaran yang dihadirkan oleh guru di dalam kelas bukan berdasarkan RPP, tetapi berdasarkan LKS yang dibuat penerbit. Guru berupaya tampil maksimal dalam menghadirkan pembelajaran yang menyenangkan pada saat dikunjungi kepala sekolah atau yang mewakilinya.
Kunjungan yang bertujuan supervisi akademis. Ketika kunjungan itu berakhir, berakhir pulalah upaya guru untuk tampil maksimal. Ia kembali pada model pembelajaran "lama", tidak memberi kesempatan siswa berdiskusi, tidak ada media pembelajaran, tidak ada permen yang dibagikan kepada siswa yang aktif.

Guru membawa RPP ke dalam kelas (diberikan juga salinannya kepada supervisor), membawa media pembelajaran yang bagus, dan menyiapkan reward bagi siswa yang aktif dalam pembelajaran. Namun demikian, RPP tinggalah sebagai "seonggok" dokumen yang tidak memiliki nilai karena tidak bermanfaat sebagai acuan pembelajaran. Meskipun RPP dibawa oleh guru ke dalam kelas, pembelajaran yang disampaikan oleh guru berbeda dengan RPP yang dibawanya. Media yang dibawa guru tidak menunjang kompetensi dasar yang harus dicapai oleh siswa. Siswa senang mendapat hadiah permen dari guru atas keaktifannya dalam pembelajaran. Setelah selesai pembelajaran, siswa saling menghitung jumlah permen yang didapatkan dari gurunya pada hari itu.

Pembelajaran di SMP Negeri 2 Greged bukan sekadar tidak efektif tetapi juga tidak menyenangkan (membosankan). Guru tidak berupaya membelajarkan siswa. Guru masuk ke dalam kelas memberikan pengajaran kepada siswa sesuai dengan suasana hatinya. Jika sedang bersemangat, ia akan berceramah selama dua jam pelajaran. Guru tidak peduli apakah siswa membuat catatan penting terhadap penjelasannya, apakah siswa mengerti materi yang dijelaskan oleh guru. Yang penting bagi guru adalah ia telah menyampaikan materi kepada siswa. Meskipun materi yang disampaikan guru menyimpang dari RPP yang dabawanya ke dalam kelas. Meskipun guru mengetahui bahwa siswa tidak memusatkan perhatian pada 
penjelasannya. Jika sedang merasa malas, guru hanya menunggui siswa mengerjakan tugas selama dua jam pelajaran. Siswa mengerjakan tugas yang terdapat dalam LKS buatan penerbit, secara perorangan maupun kelompok. Uraian pelaksanaan pembelajaran di kedua sekolah tersebut disajikan dalam hasil penelitian berikut ini.

Kegiatan pembelajaran di SMP

Negeri 3 Sumber berlangsung menyenangkan. Pada umumnya siswa menyukai gaya guru mengajar di kelas. Hal itu terlihat dari kesan siswa yang positif terhadap cara guru mengajar. Guru mengajar dengan santai, tidak terlalu serius dan penuh semangat dengan "yel-yel" yang menjadikan kelas meriah. Ia adalah guru yang ramah, dan baik hati dalam pandangan siswa.

Hasil angket menunjukkan 48,57 \% siswa merespon positif terhadap cara guru mengajar. Mereka merasa senang karena gurunya mengasyikkan, tidak galak, suka bercanda, tidak sombong dan baik hati. Sebanyak 31,42 \% siswa merasa senang karena dapat belajar secara berkelompok. Mereka menyukai kerja kelompok karena dapat bertanya kepada teman dan lebih mudah mengerjakan tugas. Dan $20 \%$ siswa merasa senang karena mudah memahami dan mengingat materi pembelajaran yang disampaikan oleh guru. Performance guru sangat baik terbukti siswa merasa senang mengikuti pembelajaran dari awal sampai akhir.

Tetapi sayang, performance guru yang sudah baik itu tidak diimbangi dengan pemahaman atas rencana pembelajaran yang sudah dipersiapkannya. Standar kompetensi yang harus dicapai oleh siswa adalah "mendengarkan" dengan kompetensi dasar "mengidentifikasi karakter tokoh novel remaja yang dibacakan dan materi pembelajarannya adalah mendengarkan cuplikan novel remaja. Namun demikian, selama pembelajaran tidak muncul kegiatan tersebut. Guru lebih menekankan pada kompetensi membaca dan berbicara. Kegiatan mendengarkan yang dilakukan oleh siswa adalah mendengarkan penjelasan guru tentang unsur-unsur intrinsik karya sastra, mendengarkan pembacaan puisi oleh seorang siswa, dan mendengarkan seorang siswa yang membacakan materi unsur-unsur intrinsik karya sastra yang terdapat dalam LKS (cetakan sebuah penerbit).

Proses pembelajaran dan penyajian bahan ajar tidak sistematis. RPP tidak menjadi rujukan guru dalam proses belajar mengajar, sehingga guru kehilangan arah dan melenceng dari rancangan yang seharusnya. Siswa dikelompokkan dari awal pembelajaran, tetapi kelompok yang sudah dibentuk tidak efektif. Guru tidak memberikan kesempatan pada kelompok untuk menampilkan hasil pekerjaan kelompoknya sehingga siswa tidak mengetahui apakah pekerjaan yang mereka lakukan sudah benar ataukah tidak. Siswa hanya diberi kesempatan mengerjakan tugas secara berkelompok kemudian mengumpulkan hasilnya kepada guru, tanpa ada upaya guru untuk memberikan masukan dan merefleksi hasil pekerjaan siswa. Padahal sebenarnya waktu yang tersedia cukup untuk melakukan kegiatan tersebut. Guru juga membuat kekeliruan ketika memberi tugas kelompok. Tugas yang diberikan kepada kelompok adalah membaca pemahaman, sedangkan kompetensi yang seharusnya adalah mendengarkan. Pembelajaran tidak hanya menyenangkan tetapi harus berlangsung efektif sebab pembelajaran dilaksanakan bertujuan membelajarkan siswa untuk mencapai tujuan tertentu yang sudah dirumuskan. Pembelajaran yang berlangsung sekadar menyenangkan tetapi tidak efektif sama saja dengan bermain. 
Kegiatan pembelajaran di SMP Negeri 2 Greged tidak kondusif dan membosankan. Pada umumnya siswa tidak menyukai guru yang asyik dengan dirinya sendiri, tidak pernah tersenyum apalagi bercanda selama dua jam pelajaran. Hal itu, terlihat dari respon siswa yang negatif terhadap cara guru mengajar. Mereka tertekan selama dua jam pelajaran dan merasa bebas begitu mendengar bel tanda pelajaran telah berakhir.

Hasil angket siswa menunjukkan 86,20 \% siswa merasa bosan dan tidak senang terhadap pembelajaran yang disampaikan oleh guru. Mereka bosan karena guru mengulang-ulang penjelasan yang sama dengan pertemuan sebelumnya. Gurunya tidak asyik karena tidak bisa diajak bergurau. Siswa tidak mengerti terhadap materi yang disampaikan oleh guru, menurut mereka materi yang disampaikan "tidak nyambung". Mereka bingung karena guru bercerita tentang Supermen, kemudian beralih ke Gatot Gaca, dan akhirnya Malin Kundang.

Sebanyak $13,79 \%$ siswa merasa senang dengan pembelajaran yang berlangsung karena mereka bisa bermain sambil belajar. Ketika Peneliti menanyakan mengapa mereka merasa senang, dengan spontan mereka menjawab, "senang saja karena kita lempar-lemparan surat, gurunya diam saja. Jika guru lain, pasti kita sudah dimarahi dan disetrap." Ternyata yang menyebabkan mereka merasa senang itu bukan pada pembelajarannya melainkan dapat bergurau selama pembelajaran.

\section{Pelaksanaan Pembelajaran di SMP yang Melaksanakan Lesson Study}

Pembelajaran yang disampaikan

oleh guru di SMP Negeri 2 Gunung Jati dan SMP Negeri 2 Plered adalah pembelajaran yang efektif dan menyenangkan. RPP yang dibuat oleh guru merupakan acuan bagi pembelajaran, sehingga tahap-tahap pembelajaran berlangsung secara sistematis dan terarah. Waktu dan kegiatan siswa dikelola secara efektif. Media pembelajaran yang digunakan sederhana namun mendukung materi dan kompetensi yang harus dicapai oleh siswa. Kehadiran observer yang mengamati kegiatan siswa menjadikan mereka mengikuti kegiatan pembelajaran dengan sungguh-sungguh dan berusaha menampilkan yang terbaik bagi kelompoknya pada saat presentasi. Secara rinci, hasil penelitian di kedua sekolah tersebut diuraikan sebagai berikut.

Kegiatan pembelajaran di SMP Negeri 2 Gunung Jati berlangsung kondusif dan menyenangkan. Semua siswa merasa senang mengikuti pembelajaran yang berlangsung selama dua jam pelajaran (80 menit). Pengelolaan waktu yang baik menyebabkan pembelajaran berjalan efektif. Kelompok yang dibentuk diberdayakan untuk memberi kesempatan pada siswa menggali kemampuan menulis dan berbicara. Setiap kelompok diberi kesempatan mempresentasikan hasil kelompoknya secara bergantian dan menanggapi kelompok yang presentasi. Siswa mersepon positif pembelajaran yang disampaikan oleh guru.

Hasil angket menunjukkan sebanyak 41,17 \% siswa merasa nyaman dan santai karena pembelajaran diselingi gurauan sehingga materi pelajaran mudah dipahami. Sebanyak 38,23\% siswa merasa senang dengan cara belajar berkelompok. Sebab dengan begitu, memudahkan mereka mengerjakan tugas. 20,58 \% siswa menyenangi pelajaran bahasa Indonesia.

Kegiatan pembelajaran di SMP Negeri 2 Plered berlangsung kondusif dan menyenangkan. Semua siswa merasa senang dan antusias mengikuti pembelajaran selama dua jam pelajaran 
(80 menit), kecuali satu orang siswa yang berbeda pendapat dengan temantemannya, ia merasa tidak senang selama mengikuti pembelajaran. Siswa diberi kesempatan untuk mengeksplorasi kemampuan menulis dan berbicara sedangkan guru bertindak sebagai fasilitator. Pengelolaan waktu yang baik menyebabkan pembelajaran tidak membosankan. Hal itu, terlihat dari respon siswa yang positif terhadap pembelajaran yang disampaikan oleh guru.

Hasil angket menunjukkan sebanyak 56,75 \% siswa merasa senang karena gurunya asyik, suka bercanda sehingga pelajaran mudah dipahami dan tidak membosankan. $18,91 \%$ siswa merasa senang karena cara guru mengajar yang sangat baik dan materi pelajaran menyenangkan. 16,21\% siswa merasa senang karena diberi kesempatan belajar bersama kelompok, kemudian maju mempresentasikan hasil kelompoknya. Menurut siswa kegiatan tersebut melatih mental dan menumbuhkan rasa percaya diri. 5,40\% siswa merasa senang belajar berkelompok sehingga mereka dapat bersosialisasi dengan teman dan cepat mengerti. 2,70 \% siswa merasa tidak senang karena teman-temannya kurang rapi dalam belajar. Ketika Peneliti menanyakan kepada siswa tersebut, mengapa tidak senang pada pelajaran ibu Ana. Siswa menjawab "bukan pada bu Ana sebab orangnya asyik." Ternyata siswa tidak menyukai tulisan temantemannya di papan tulis yang tidak rapi "naik turun tidak beraturan". Jadi bukan pada pembelajaran yang disampaikan oleh guru.

\section{Pelaksanaan Refleksi Pembelajaran di SMP yang Tidak Melaksanakan Lesson Study \\ Refleksi \\ pembelajaran dilakukan pada akhir proses (kegiatan penutup) pembelajaran untuk}

memberikan penguatan atau mengevaluasi proses kegiatan inti dan mengecek tingkat penguasaan siswa terhadap materi pelajaran yang telah diberikan (Budimansyah, 2010: 154). Kegiatan refleksi dapat berupa pertanyaan mengenai kekurangan dan keuntungan dari hasil pelaksanaan kegiatan, pertanyaan tentang konsep penting yang dapat dipetik dari proses pembelajaran, atau kesan siswa terhadap proses pembelajaran.

Refleksi pada tahap see
dimaksudkan untuk menemukan kelebihan dan kekurangan pelaksanaan pembelajaran. Hal itu, dilaksanakan melalui diskusi antara guru model, observer pada fase do, pengawas akademis, dan fasilitator lesson study.

Di SMP Negeri 3 Sumber dan di SMP Negeri 2 Greged, guru tidak melaksanakan refleksi pada akhir pembelajaran. Di SMP Negeri 3 Sumber siswa hanya mengumpulkan tugas kelompok setelah selesai pembelajaran. Guru tidak memberikan kesempatan pada kelompok untuk menggali kemampuannya, hanya sekadar mengerjakan tugas bersama-sama, menuliskannya di lembar kerja sebagai laporan, lalu mengumpulkannya kepada guru pada saat pembelajaran berakhir. Siswa tidak mengetahui apakah pekerjaan yang mereka lakukan sudah benar atau masih ada kesalahan yang harus diperbaiki.

Di SMP Negeri 2 Greged pembelajaran berlalu begitu saja. Siswa tidak diberi tugas, tidak diberi kesempatan belajar berkelompok, siswa hanya mendengarkan uraian guru selama dua jam pelajaran. Setelah itu, siswa tidak mendapatkan apa-apa. Siswa bingung apa yang sebenarnya dijelaskan oleh guru. Mereka tidak mengerti (kaga nyambung istilah yang mereka sebutkan dalam angket) ketika guru menceritakan Superman, kemudian beralih kepada 
Sule, dan beralih lagi kepada Malin Kundang.

\section{Pelaksanaan Refleksi Pembelajaran di SMP yang Melaksanakan Lesson Study}

Di SMP Negeri 2 Gunung Jati refleksi dilaksanakan pada akhir pembelajaran berupa pengecekan terhadap pemahaman siswa pada proses pembelajaran yang berlangsung. Pertanyaan yang diajukan guru mendapat respon positif dari siswa. Kemudian guru mengarahkan siswa pada kesimpulan bahwa materi pembelajaran yang mereka dapatkan pada saat itu, penting artinya bagi kehidupan mereka. Dengan demikian, setelah selesai pembelajaran siswa mengetahui mafaat yang penting dari pembelajaran bagi kehidupan mereka.

Refleksi pembelajaran di SMP

Negeri 2 Plered dikukan oleh guru dengan cara memberikan kesan kepada siswa. Mengumumkan hasil terbaik yang diperoleh siswa merupakan reaksi positif yang ditampilkan oleh guru dan merupakan penghargaan bagi prestasi yang telah dicapai oleh siswa. Hal ini, merupakan motivasi bagi siswa. Siswa merasa senang karena hasil pekerjaannya diharagai oleh guru. Selanjutnya guru menginformasikan pembelajaran yang akan datang.

Refleksi pembelajaran tidak hanya dilakukan setelah pembelajaran di dalam kelas oleh guru dan siswa, melainkan dilaksanakan pula bagi guru dan teman sejawat dalam fase see. Pada kegiatan refleksi tersebut guru di SMP Negeri 2 Gunung Jati dan SMP Negeri 2 Plered mendapatkan masukan yang berharga bagi perbaikan pembelajaran yang berlangsung di dalam kelas. Guru yang menjadi observer pun mendapat pengalaman berharga dari guru model. Ia dapat mengamati kekurangan dan kelebihan yang dilakukan guru model pada saat menyampaikan materi, menggunakan alat pelajaran maupun pengelolaan kelas. Hal itu menjadi bahan masukan baginya ketika observer kembali ke kelasnya untuk mengajar dan membelajarkan siswanya.

Refleksi pembelajaran yang dilaksanakan di kedua sekolah tersebut menimbulkan kesan positif bagi siswa. Mereka memahami kebermaknaan materi yang dipelajari bagi kehidupan mereka. Mereka mengerti mengapa materi pembelajaran itu penting. Selain refleksi setelah kegiatan pembelajaran, dilakukan pula refleksi antarguru, pengawas, fasilitator, dan kepala sekolah yang bertujuan membahas kelemahan dan kesulitan siswa dalam pembelajaran untuk dicarikan solusinya bersama-sama. Keterbukaan dalam fase see memungkinkan setiap peserta lesson study mendapatkan manfaat bagi peningkatan kompetensi pedagogik yang dimilkinya.

\section{SIMPULAN}

Implementasi lesson study berdampak positif bagi pembinaan dan peningkatan kompetensi pedadogik guru bahasa Indonesia. Setelah mengikuti lesson study guru memiliki kemampuan yang memadai dalam merancang rencana pelaksanaan pembelajaran. Hal itu, terbukti dari skor yang diperoleh guru yang tidak melaksanakan lesson study dalam mempersiapkan pembelajaran termasuk kategori tidak baik (skor 11). Setelah melaksanakan lesson study skor naik menjadi 31 dan 32 yang termasuk kategori baik. Begitu juga kemampuan dalam melaksanakan kegiatan pembelajaran di dalam kelas. Guru yang tidak melaksanakan lesson study termasuk kategori kurang baik dan tidak baik dengan skor 60 dan 41, sedangkan guru yang telah melaksanakan lesson study kemampuan melaksanakan pembelajaran termasuk kategori baik dengan skor 102 dan 105. Guru yang melaksanakan lesson study terbiasa 
melakukan refleksi pada akhir pembelajaran. Melalui kegiatan plan, guru mendapat masukan untuk perbaikan penyusunan RPP sebelum disampaikan kepada siswa. Guru berkesempatan merevisi RPP yang sudah dirancangnya. Revisi tersebut, dapat berupa rumusan tujuan pembelajaran, penyusunan langkah-langkah pembelajaran, sampai dengan penyusunan instrumen penilaian. Ketika guru memasuki kelas, ia dalam kondisi yang siap dan percaya diri karena RPP yang "dibawa" ke dalam kelas merupakan hasil rancangan bersama guru sebidang dengan meminimalisasi kemungkinan kendala yang dihadapi di dalam pengelolaan pembelajaran.

$$
\text { Kesiapan guru dalam }
$$

perancangan rencana pembelajaran berdampak positif bagi pembelajaran yang menyenangkan dan efektif di dalam kelas. Pembelajaran dilaksanakan secara sistematis dan terarah. Kehadiran observer selama pembelajaran untuk memantau kegiatan siswa memungkinkan terdeteksinya kesulitan siswa dalam belajar secara optimal. Pemantauan kegiatan pembelajaran pada siswa menyebabkan kesulitan dan kelemahan siswa dalam belajar dapat diketahui secara merata. Kesulitan dan kelemahan selama pembelajaran dibahas dalam fase see untuk dicarikan jalan keluarnya. Tahap-tahap yang dilalui guru dalam lesson study memungkin guru terus berkembang ke arah yang lebih baik. Selain bermanfaat bagi guru model, pelaksanaan lesson study memungkinkan pula para observer untuk belajar dari pembelajaran guru lain. Pembelajaran yang dilakukan oleh observer pada saat kembali ke dalam kelasnya akan terkoreksi. Dengan sendirinya, ia akan membandingkan pembelajaran yang dilakukannya dengan pembelajaran yang dilihatnya pada fase do. Guru yang memiliki semangat untuk terus belajar dan memperbaiki diri berdampak positif bagi mutu pembelajaran di dalam kelas.

\section{UCAPAN TERIMA KASIH}

Peneliti mengucapkan terima kasih kepada guru-guru SMP di Kabupaten Cirebon yang telah membantu pelaksanaan penelitian ini. Ucapan terima kasih juga disampaikan kepada pimpinan Pascasarjana Unswagati yang telah mendukung sepenuhnya penelitian ini.

\section{PUSTAKA RUJUKAN}

Hendayana, Sumar, et al. 2006. Lesson Study, Suatu Strategi untuk Meningkatkan Keprofesionalan Pendidik (Pengalaman IMSTEP-JICA). Bandung: UPI Press

Hendayana, Sumar, et al. 2011. Implementasi Lesson Study, Diseminasi Program Lesson Study PHK-I di Sepuluh Kabupaten/Kota di Jawa Barat Tahun 2011-2013. Bandung: BPPTKPU

Idrus, Muhammad. 2009. Metode Penelitian Ilmu Sosial, Pendekatan Kualitatif dan Kuantitatif Edisi kedua. Jakarta: Erlangga

Lewis, Chaterine C. 2002. Lesson Study: A Handbook of Teacher-Led Instructional Change. Philadelphia, PA: Research for Better School. Inc. Tersedia online di http://www.sowionline.de/journal/20021/lesson lewia.htm

Muhadjir, Noeng. 2002. Metodologi Penelitian Kualitatif. Yogyakarta: Rake Sarasin

Mulyana, Slamet. 2007. Lesson Study (makalah). Kuningan: LPMPJawa Barat 
Peraturan Pemerintah Nomor 19 Tahun 2005 tentang Standar Nasional Pendidikan

Raco, J.R. 2010. Metode Penelitian Kualitatif; Jenis, Karakteristik, dan Keunggulannya. Jakarta: Grasindo

Santana K, Septiawan. 2010. Menulis Ilmiah Metodologi Penelitian Kualitatif Edisi kedua. Jakarta: Yayasan Pustaka Obor Indonesia

Sugiyono. 2011. Metode Penelitian Kuantitatif, Kualitatif, dan $R \& D$. Bandung: Alfabeta
Susilo, Herawati, et al. 2011. Lesson Study Berbasis Sekolah, Guru Konservatif Menuju Guru Inovatif. Malang: Bayu Media Publishing

Tim JICA (Japan International Cooperation Agency). 2009. Panduan untuk Peningkatan Proses Belajar dan Mengajar, Program Peningkatan Kualtias (PELITA SMP/MTs). Jakarta: IDCF (International Development Centre of Japan)

Undang-undang RI Nomor 14 Tahun 2005 tentang Guru dan Dosen 